\title{
The Rise and Decline of Comprehensive Education: Key Factors in the History of Reformed Secondary Education in Belgium, 1969-1989
}

\author{
Bregt Henkens \\ K.U. Leuven, Belgium
}

In answer to economic needs and social demands, a structural innovation was introduced in secondary education in most West European countries, mainly in the 1960s. Contrary to the traditional schools, organized in vertical categories, the so-called comprehensive schools brought together all branches in one school. There was protest against this type of school from the start but it was mainly in the 1980s and 1990s that comprehensive schools came under siege. In most countries the comprehensive structures have been abandoned or adjusted to a more moderate form.

This paper tries to explain the factors that stimulated innovation in the 1960s, and those that counteracted comprehensive education. As will be shown, these factors were not always related to ideological positions. In fact, the reasons for local educational authorities to "go comprehensive" (or not) were often practically rather than ideologically inspired. Theories of "dominant rationality" by Matthijssen and the "referential" by Jobert succeed in surpassing ideological parameters, and can be interesting tools to explain changing mentalities. However, a satisfying explanation for the history of comprehensive education cannot be offered without paying attention to everyday pragmatics, that - in the author's view - have been decisive for the evolution of comprehensive education.

The paper will be illustrated with examples from the Belgian case. Comprehensive schools were introduced in Belgium in 1969. All state public schools went comprehensive in the 1970s, and the number of comprehensive private schools grew rapidly until growth ceased around 1980. The ongoing struggle between Catholic comprehensive and traditional schools led to a compromise created by the Catholic educational authorities, a fusion of comprehensive and traditional elements. This structure was imposed by the Flemish government as a unitary structure for all secondary schools in the Dutch-speaking part of Belgium in 1989.

\section{Introduction}

After the Second Word War, the structure of post-primary education in most West European countries was still largely the same as in the nineteenth century. Notwithstanding the many types and forms of education, secondary schools could be categorized into different streams, with a difference in curriculum and in the social origin of the pupils. In Belgium, as in several other countries, secondary education was vertically divided into a classical stream - general secondary schools with a Latin and/or Greek-based curriculum; a modern stream - general secondary 
education without Latin or Greek; and technical and vocational streams - the former being more theoretically oriented, the latter more practically. Ringer describes such an educational system as "segmented". This traditional structure, Ringer says with reference to Pierre Bourdieu, tended to "reproduce and to fortify the class and status structures of society". ${ }^{1}$

In the course of the twentieth century, the traditional educational system came under pressure. The main objection was that it did not respond to the current social and economic needs and expectations. Especially in the decade after the Second World War, manifesting a deficiency of skilled workers and a growth of social demands (for equal opportunity and equal access to education), educational innovation obtained its place on political agendas. In the first years after the war the basis for future reforms was already delineated by projects in different countries: the Education Act in Britain (1944), the Swedish School Commission (1946), the Langevin-Wallon report in France (1947), the publications of "educational adviser" Marion Coulon in Belgium (1947). ${ }^{2}$ Common to these projects was the tuning in of the different sections in secondary education. They led to the creation of multilateral schools and/or the organization of - at least lower secondary education in a sort of common school or common cycle (called "orientation cycle" by Langevin-Wallon and Coulon). ${ }^{3}$ The idea was to postpone the organizational differentiation "in terms of tracking and streaming for as long as possible in order to reduce, if not entirely eliminate, the influence of social and cultural background". 4

Mainly in the 1960s and 1970s common schools and common cycles became broadly implemented in secondary education in several West European countries. In Sweden, for instance, the common Grundskola, which had existed as an experiment since 1949, was generalized in 1962. Italy began the implementation of comprehensive "middle schools" the same year. In the Netherlands, the law on secondary education of 1963 provided a common curriculum in the first year. The French government established common observation (1959) and orientation (1963) cycles and brought together the "long" and "short" sections of this four-year secondary first cycle into the multilateral Collèges d'enseignement secondaire (CES) in 1963 (the Fouchet-Capelle reform). In 1975, the CES and the Collèges d'enseignement

\footnotetext{
${ }^{1}$ Preface to Detlef Müller, Fritz Ringer \& Brian Simon (Eds), The Rise of the Modern Educational System: Structural Change and Social Reproduction, 1870-1920 (Cambridge/Paris, 1987), p. xii.

${ }^{2}$ Gary McCulloch, Educational reconstruction: the 1944 education act and the twenty-first century (London, 1994); Stephen J. Ball \& Staffan Larsson, The struggle for democratic education: equality and participation in Sweden (New York, 1989); Jean-Michel Barreau, Jean-Francois Garcia \& Louis Legrand, L'école unique (de 1914 à nos jours) (Paris, 1998); Marion Coulon, Jeunesse à la derive: Pour une novelle structure des enseignements superieurs (Mons, 1947); Achim Leschinsky \& Karl Ulrich Mayer (Eds), The comprehensive school experiment revisted: evidence from Western Europe (Bern, 1990).

${ }^{3}$ In multilateral schools all streams - general, technical, vocational - are brought together in one school. Within the school, however, the different sections remain distinct. This distinction disappears in a common school or cycle. All pupils follow a common curriculum.

${ }^{4}$ Erik Wallin, "The Comprehensive School - the Swedish Case", European Journal of Education, XXVI (1991), p. 144.
} 
général (CEG, former primary cours complémentaires) were replaced by a Collège unique that amalgamated the different sections into one common cycle (the Haby reform). In England and Wales, the Labour government asked the Local Education Authorities (LEAs) in 1966 to adopt the comprehensive structure, which had existed alongside grammar, technical and secondary modern schools since the 1944 Education Act. The Education Ministers of the German Länder decided in 1969 to start an experiment in comprehensive schooling. The same year, a common structure, called Reformed Secondary Education (RSE), was introduced in Belgian schools.

This paper focuses mainly on the Belgian experience of comprehensive schooling. Our focus will be on the factors that stimulated this reform in the 1960s and 1970s, and slowed it down from the late 1970s onwards. We will interpret these factors by using such concepts as "ideology", "rationality", "referential" and "pragmatism" (in the political, not the Deweyan sense). But first, let us examine what the Belgian version of comprehensive education looked like.

\section{The comprehensive school reform in Belgium}

The realization and evolution of Reformed Secondary Education (RSE) in Belgium cannot be understood without paying attention to the structure and conditions of the educational system. Belgium has always known a very strong private education sector. ${ }^{5}$ The principle of "freedom of education" was enshrined in the Belgian constitution (1831), stating: "Education shall be free; any preventive measure is prohibited; the repression of offences shall be a matter for the state alone. Public education provided at the expense of the state shall also be subject to the law." This meant literally that any individual or organization could create schools without any state interference. In 1958, after years of struggle between the Christian-democratic party, trying to increase subsidies to denominational (mostly Catholic) schools, and the Socialist and Liberal parties, trying to expand the state public school sector, representatives of the political parties concluded a so-called "School Pact". Since then, Belgian schools have been structurally divided into three networks: the state public sector, the local public sector and the "free" (i.e. private) sector. The last, of which the vast majority are Catholic schools, is subject to governmental control in order to receive grants. The School Pact also stipulated that every structural change in the education system had to result from negotiations between representatives of the different networks.

Such negotiations were initiated in 1964. The Belgian Education Ministers discussed a possible reform of secondary education with representatives of the three education sectors, the inspectorate, trade unions and parent organizations. Experiments with a common first grade had already been running for some years in the state public schools but the purpose of these negotiations was to create a structure that would be adopted by all schools in both the public and private sectors. However, it was not until 1969 that RSE was introduced, and 1971 that the law on RSE was voted on in Parliament. The negotiations lasted this long because the demands of the different sectors had to be conciliated but also because of

\footnotetext{
${ }^{5}$ Jeffrey Tyssens has related this proportion to the social origin of the educational system; see below.
} 
government instability. The short average lifetime of governments in those days was partly due to the linguistic conflict. Belgium is essentially a bilingual country, with the Dutch-speaking Flemings in the north, the French-speaking Walloons in the south, and a bilingual capital, Brussels. ${ }^{6}$ Since 1961, Belgium had two Ministers of Education - in fact a minister and a vice-minister from 1961, and two ministers since 1968 - responsible for French and Flemish schools, respectively.

The main objectives of the RSE (Vernieuwd Secundair Onderwijs in Flemish, Enseignement Secondaire Rénové in French) were described as providing all students with a broader basic education, postponing the choice of specialization and making it more dependent on the individual aptitudes and interests of the students than on their socioeconomic background, bridging the gap between school and the "real world", enhancing the satisfaction and self-esteem of the pupils, facilitating the switch from one section to another. Therefore an inclusive multilateral structure was created that amalgamated general, technical and vocational education under one roof (only special education was left out). In contrast with the vertical segmentation of "traditional" education into strictly separate education streams (general "academic" education - Latin or Modern -, technical education and vocational education), an education was provided that was split into three horizontal layers: an observation, an orientation and a determination grade. Instead of a study choice right from the start (at age twelve), as pupils in the traditional system had to make, opting between general, technical or vocational schools, the choice could be postponed. In the observation grade (the first two years of the reformed school), all pupils followed a largely common curriculum, which formed a common basis for all further specialization. In the second year, a number of optional subjects could be started but these had no effect on further specialization. Pupils were "observed"; that is, their capabilities, interests and talents were stimulated and studied. On the basis of these observations, pupils would be assisted in their choices for further specialization.

The next two years constituted an orientation grade, in which the common curriculum was reduced. Partly by selecting specific options, pupils could begin to orient themselves in a particular direction. They could opt for the transition stream (general, technical or artistic education), preparing for higher education, or for the qualification stream (vocational and artistic education, short term at the end of the fourth year or long term at the end of the sixth year), preparing directly for employment. However, this choice was not yet final, for even during and at the end of the second grade there were possibilities to change direction. The final choice only came with the transition to the third grade, the determination grade, which involved establishing the specialist subjects for school graduation by modifying the range of subjects through complementary options, to suit individual talents and interests. ${ }^{7}$

\footnotetext{
${ }^{6}$ Abstraction is made here of a few eastern municipalities with a German-speaking majority. After the state reform of 1988-1989 this German community would also receive full autonomy in educational, cultural and related matters.

${ }^{7}$ On the comprehensive education reform in Belgium see, e.g., Jacqueline Beckers, "Les politiques scolaires de l'égalité des chances et de l'égalité des acquis dans l'enseignement secondaire (après 1945)", in: Dominique Grootaers (Ed.), Histoire de l'enseignement en Belgique (Brussels, 1998, pp. 303-371); Anne Van Haecht, L'enseignement rénové: de l'origine à l'éclipse (Brussels, 1985); Willy Wielemans, "Comprehensive Education in Belgium: a Broken Lever?”, European Journal of Education, XXVI (1991), pp. 167-178.
} 


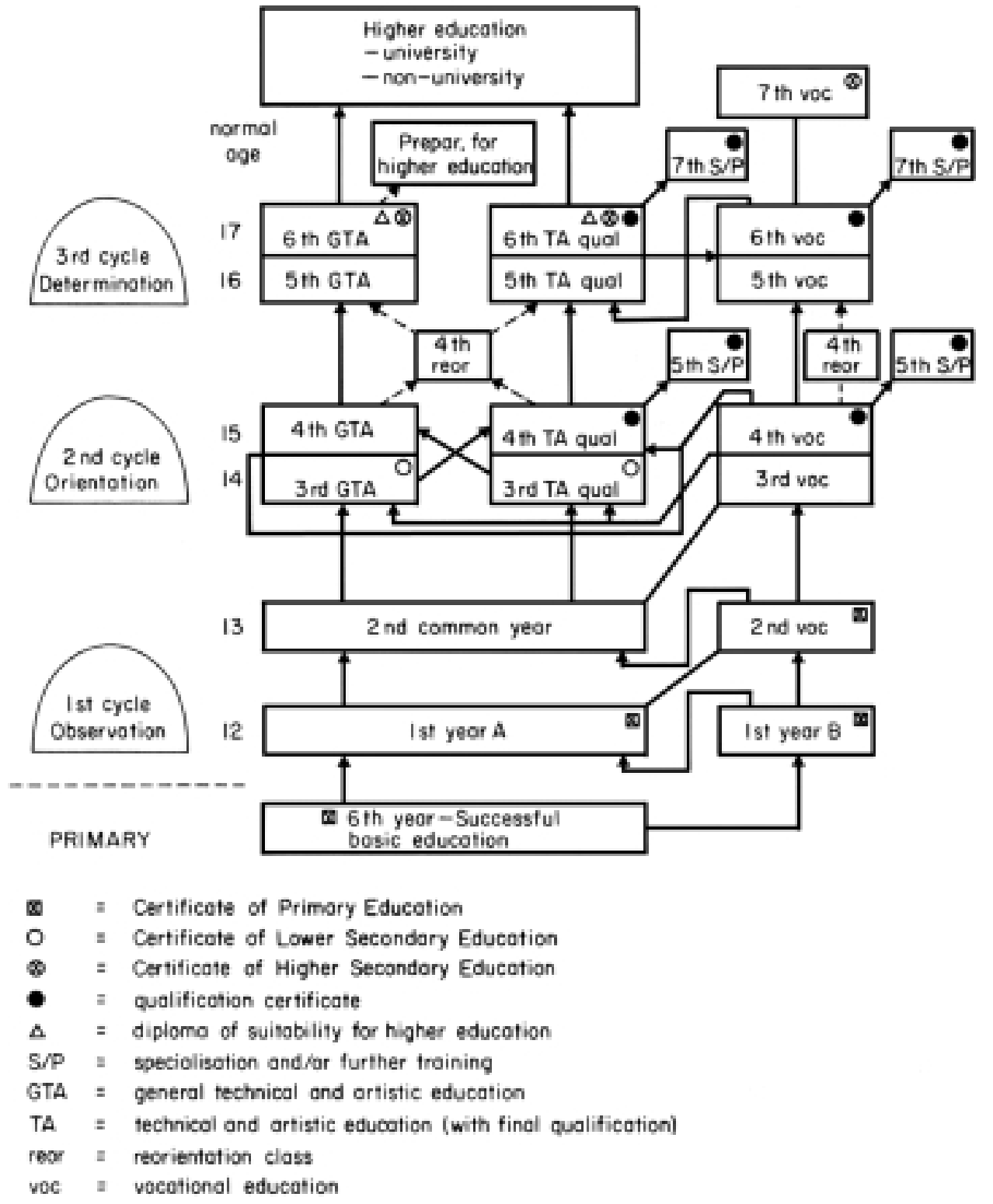

Figure 1. Diagram of the state secondary education system (type 1) in Belgium. Source: Ministry of Education, Educational Developments in Belgium. Developments in Education: 1986-1988 (Brussels, 1988), p. 25.

As well as this structural change, reform of content was also in mind. New subjects appeared on the curriculum, such as social education and technology, and the contents of existing subjects were more closely linked to the "real" world. New teaching methods introduced child-centred education, replacing the teacher as central authority figure. The teacher had to take steps to become more of a guide for conveying culture. Pupils had to be observed, guided and oriented more 
individually than before. For that purpose, adaptation classes and reorientation lessons were created and the individual pupil files were kept up to date at class deliberation boards. Particular attention would be paid to "learning to learn". The competitive spirit of the traditional education system had to make way for a spirit of cooperation. The traditional one-way traffic from teacher to pupil had to be replaced with a "democratic" relationship between teacher and pupil, with group work, independent work, class discussions, project teaching and so on. Instead of the old examination system, the pupils would have to be assessed on a continual basis, not only on factual knowledge but on attitude as well.

The reform was applied in a limited number of "pilot" schools in 1969. In the 1970 s, the number of schools that changed over to the new structure grew dramatically, in both the public and private networks. In 1975, the Minister of Education (Flemish sector) imposed the comprehensive school structure on all the institutions under the Flemish State Public Education Network, and in 1978, the entire French-speaking State Public Education Network followed this example. ${ }^{8}$ Not only was the timing of generalization of comprehensive schooling different in Flemish- and French-speaking public schools but there were also some differences in structure and curriculum. These differences emanated from the fact that Belgium was, at that time, a state in a period of reform. Between 1970 and 1989 the unitary kingdom evolved into a federal state. In 1989, Education would become the responsibility of autonomous community parliaments and governments.

Meanwhile, the comprehensive reform was introduced into free schools. The Catholic variant of RSE, which was developed in the National Secretariat for Catholic Education, was less diversified and seemed structurally closer to the traditional education system. In addition, there was an important difference in the implementation of the reforms between the Flemish- and the French-speaking Catholic Education networks. Whereas, by 1979, 90\% of the French-speaking Catholic secondary schools had changed over to the reformed system, only about $10 \%$ had in Flanders. ${ }^{9}$ The Catholic policy-making bodies had no intention of

\footnotetext{
${ }^{8}$ Royal Decree on the organization of secondary education of 31 July 1975; Ministerial Decree of 5 January 1978.

${ }^{9}$ De Keyser and D'hoker relate this difference to the orientation of the French-speaking community towards France, where - as described above - comprehensive ideas had been circulating for a longer time (Raf De Keyser \& Mark D'hoker, "De geschiedenis van het secundair onderwijs in België", Nova et Vetera, XLII (1984-1985), pp. 15-40). The French community knows also a broader adherence to social progressive ideas, c.q. a stronger position of the Socialist Party. Roger Standaert, formerly responsible for the implementation of RSE in the Flemish Catholic schools, says that the French schools opted faster for RSE because of their minority position with regard to public schools in the south of Belgium whereas in Flanders Catholic secondary schools outnumbered the public schools by far. When all the public schools changed over to RSE, the French schools - in their weak position - were obliged to follow (interview by the author, 10 July 2001). Antoon Boone, former secretary-general of the Catholic network of technical and vocational schools, relates the difference to the high concentration of secondary schools in city areas in Flanders, whereas in the south the supply of schools was much lower. Therefore it was more interesting for those French schools to expand towards the multilateral RSE (interview by the author, 13 July 2001).
} 
enforcing changeover to comprehensive education for all Catholic schools. The competition between Catholic schools of the reformed and the traditional structure - named "type I" and "type II", respectively, since 1975 - led to what became known as the "conflict of types".

There were protests against comprehensive schools right from the start but it was mainly in the late 1970 s and the 1980s that comprehensive schools came under siege in most of the countries that had initiated the reform in the 1960s. In some countries the number of comprehensive schools in the education system was minimized, in other countries comprehensive structures were adjusted to a more moderate form. In Flanders, a so-called "Unitary Structure", a compromise between comprehensive and traditional elements, was imposed on all Flemish secondary schools, public as well as free, on 1 September 1989.

The following sections will provide some outlines on how this evolution might be explained.

\section{Ideological factors in the history of comprehensive education}

One could explain the contrapositions regarding comprehensive education from an ideological point of view. An interesting way of explaining ideological conflicts in education policy is to study the social origin of the educational system, as was done by Margaret Archer for England and France, and by Jeffrey Tyssens for Belgium. ${ }^{10}$ Yet, however interesting it may be to interpret conflicts regarding the relation between public and private schools, this neo-Weberian model fails when it comes to explaining the type of conflict that has arisen around comprehensive education. For this was not in the first place a conflict based on religious conviction or on the mission of the state in education. Partisans and opponents of RSE could be found within both the public and the free sectors.

Usually, the sides for and against reformed education are identified with social groups that are supporters of a progressive or a conservative ideology, respectively. The progressives would encourage the comprehensive structure because it would promote social mobility and be egalitarian, the conservatives would oppose the system for the same reasons. The latter would argue that through the so-called "levelling" action of the common curriculum and heterogeneous classes, the more intelligent pupils would be dulled and the overall level would degrade. In the most pessimistic scenarios it would, it was said, even lead to the fall of Western civilization.

This ideological angle could be illustrated by looking at the evolution of comprehensive schooling in England and Wales in the 1960s and 1970s. Labour governments have taken a more encouraging stance with regard to the comprehensive system than have Conservative governments. The most important step was Circular 10/65, in which the Labour government of 1965 urged local authorities "to prepare and submit to him [the Secretary of State for Education] plans for reorganizing secondary education in their areas on comprehensive lines" (Circular $10 / 65)$. Conservative educationists have tried to defend the variety of schools envisaged in the 1944 Education Act against the "enforced uniformity of

\footnotetext{
${ }^{10}$ Margaret S. Archer, Social Origins of Educational Systems (London, 1984); Jeffrey Tyssens, Strijdpunt of pasmunt? Levensbeschouwelijk links en de schoolkwestie 1918-1940 (Brussels, 1993).
} 
comprehensive education". ${ }^{11}$ It is an old Tory principle that "unless it is necessary to change, it is necessary not to change". The Conservative educationists did not want a uniform national plan and saw no reason why good grammar schools, technical or modern schools should be swept away for something that may have been no better and might have been worse. The Conservative Party Manifesto of 1955 stated that "to prepare for the increasing opportunities of the modern world we need all three kinds of secondary school, grammar, modern and technical, and we must see that each provides a full and distinctive education. We shall not permit the grammar schools to be swallowed up in comprehensive schools". The party denounced what it saw as Labour's desire to use the social services as an instrument for levelling down. Furthermore, the educational system of comprehensive schools was thought to stand in contrast with the Conservative philosophy of education. As Minister of Education Sir David Eccles wrote to the principals of all teacher training colleges: "the schools themselves - as Plato and Aristotle first told us - have a special responsibility in shaping and upholding the ends which society should pursue. Therefore, the school should be a place were good citizens are formed and where discipline is maintained". ${ }^{12}$ The Conservative educationalists' concern was therefore the struggle to move away from the style and priorities of the comprehensive school. While the Labour government was preparing a bill that imposed the comprehensive structure, ${ }^{13}$ this attempt was nullified when the Conservatives came to power in 1970. In Circular 10/70, Margaret Thatcher, Secretary of State in the Heath Government, endorsed the LEA's freedom to choose an educational structure. The Labour government that ruled from 1974 to 1979 reaffirmed the commitment to a comprehensive ideal by linking public grants for grammar schools to the adoption of a comprehensive structure. The Thatcher government, formed in 1979, pushed education policy in the other direction again, sponsoring a "staged return" to academic selection. ${ }^{14}$

In Belgium, too, one can see clearly the influence of ideology in the history of the comprehensive reform. Comprehensive schooling was introduced by two Socialist Ministers of Education in 1969-1970. They motivated the reform by referring to it as a "preparation for life in the twenty-first century". ${ }^{15}$ The same argument was used by the influential progressive Catholic professor C.C. De Keyser, who declared that education in the year 2000 would be comprehensive, or would not be at all. ${ }^{16}$ In the Netherlands, Social-democrat Education Minister Jos van

\footnotetext{
${ }^{11}$ Christopher Knight, The Making of Tory Education Policy in Post-War Britain, 1950-1986 (London, 1990).

${ }^{12}$ Memorandum by Sir David Eccles to principals of all training colleges, 6 October 1961, The Longden Papers. Quoted in Knight, The Making, p. 15.

${ }^{13}$ This led to the accusation that Labour was dictatorial, but Ted Short, Labour's Secretary of State, replied: "If it's wrong to select and segregate children, it must be wrong everywhere". Quoted in Tony Edwards, Geoff Whitty \& Sally Power, "Moving Back from Comprehensive Secondary Education", in Jack Demaine (Ed.), Education Policy and Contemporary Politics (Basingstoke, 1999), p. 30.

${ }^{14}$ Edwards, Whitty \& Power, "Moving Back", pp. 30-32.

${ }^{15}$ Abel Dubois, L'Enseignement secondaire rénové (Brussels, 1972), p. 25.

${ }^{16}$ Cyrille C. De Keyser, Naar een comprehensief Europees basisonderwijs voor het jaar 2000. Vergelijkend historisch essay over de dialectiek tussen twee maatschappij- en onderwijsmodellen exemplarisch verduidelijkt aan Frankrijk en België (Leuven, 1986).
} 
Kemenade began an experiment with middle schools in 1976. Thus, secondary education was to provide "education for democracy" instead of "education for manpower". ${ }^{17}$ In Germany, the striking differences in the implementation of comprehensive schools in the different Länder in the 1980s could be related to the parties that steered educational policy. In North-Rhine-Westphalia and Hessen, dominated by Social-democrat governments, there were respectively ninety-five and seventy-one comprehensive schools in 1987, whereas Bavaria, Baden-Wurttemberg and Schleswig-Holstein, three Länder with a longstanding conservative (CDU/ CSU) education policy, had no more than two each. ${ }^{18}$ The first thorough adjustment in comprehensive education in Belgium took place during the term of office of the (conservative) Liberal Education Minister Herman De Croo (1974-1977): the freedom of choice of the modular system was cut down, the subject "social education" had to bow to the return of "history", the loose evaluation system was replaced by a more traditional-style examination system with summate and formative tests, and more homogeneous classes became the aim. ${ }^{19}$ In this way, it corresponded more closely again to traditional education. These reforms were a thorn in the side of the Socialists who had originally created the comprehensive structure, so De Croo's successor, Jef Ramaekers from the Socialist Party, therefore reintroduced the modular system.

On the other hand, the expansion of comprehensive education is not solely a socialist merit. In France, for instance, the reforms of 1959 and 1963 that united the different strands of secondary education in a multilateral school were carried out by the conservative Debré and Pompidou governments; the introduction of the Collège unique (1975), a comprehensive unitary school for all pupils from eleven to sixteen, was the work of the conservative Chirac cabinet. In the German Länder of West Berlin and Saarland, the proportion of comprehensive schools grew when the CDU came to power. In Belgium, a multilateral school model was developed by the moderate right-wing Vanden Boeynants government in 1967 - but was never implemented because of the overthrow of the cabinet. And despite the abovementioned progressive criticism of the De Croo reform, it was he who generalized comprehensive education in the state sector. Furthermore, when we take a look at the evolution of comprehensive education in the 1980s and 1990s, it is obvious that ideology-based theories cannot explain the fact that even left-wing parties distanced themselves from the comprehensive ideas of the $1960 \mathrm{~s}$.

Besides, political parties should not be viewed as ideological monoliths. In the UK, for instance, not all Labour MPs were convinced that the comprehensive system was the best thing for British youth. In 1961, the "61 Society" was created by kindred spirits from both Labour and Conservative parties, acting against "the pace of change from the tripartite system to comprehensive education without any proper research". ${ }^{20}$ They perceived that comprehensivization was threatening to destroy

\footnotetext{
${ }^{17}$ Jos Van Kemenade, Als de smalle weegbree bloeit. Opstellen over onderwijs en onderwijsbeleid (Amsterdam, 1979), p. 48.

${ }^{18}$ Wolfgang Mitter, "Comprehensive Schools in Germany: Concepts, Developments and Issues”, European Journal of Education, XXVI (1991), p. 158.

${ }^{19}$ Royal Decrees on the organization of secondary education of 31 July 1975 , and 30 July 1976.

${ }^{20}$ Harry Greenway to Knight, 23 January 1986. Quoted in Knight, The Making, p. 16.
} 
existing good schools. On the other hand, local Conservative councils were often proud of their "progressive educational policy". ${ }^{21}$ They argued that "comprehensive education was as much the property of the Right as the Left". ${ }^{22}$ In Belgium, several Socialist MPs resisted the generalization of comprehensive education in state public schools, mainly because they feared that this would cause a disadvantage in the competition with the private sector. The most serious controversies concerning RSE existed within the Christian Democratic Party, to which belonged the most radical partisans of both traditional and comprehensive education.

Moreover, one may offer a convincing argument that "ideological" parameters are not enough when it comes to interpreting the discord between supporters and opponents of educational reform. They take too little account of current social developments in which policy decisions are necessarily embedded. For, as the British educational sociologist Bellaby laconically stated with regard to comprehensive schooling: the theories may come from the educationists and the will to reform from the politicians but these protagonists get their ideas from what goes on in society. ${ }^{23}$ The Belgian educationist Wielemans goes even further. Education policy is characterized by the lack of own normativity, he says. It is conducted by dominants coming from outside education. ${ }^{24}$

We must not lose sight of the fact that there have been many criticisms of educational reform other than just the aforementioned "levelling action". In Belgium, many progressives saw RSE as a "missed opportunity"; for them, comprehensives did not go anywhere near far enough, and reformed education failed in the objective of producing social transformation. On the communist side, it was argued that it was merely a refinement of the capitalist reproduction system that just kept working-class children more efficiently under the thumb. Many historians and classicists were opposed to the decrease of hours of Latin and to the fact that the subject "history" was replaced by "social education". Some teachers were simply dissatisfied with the quick introduction of comprehensive education and with the poor guidance. Finally, many people were irritated by the high cost of RSE. It is clear that these people represent a diversity of interests. Therefore one cannot speak of a purely ideological controversy. As educational innovation often reflects changes in society, one should perhaps take a better look at the thoughts that steer policy as a whole.

\section{The history of comprehensive education related to "rationality" and "referentials"}

For this subject, a more interesting concept than ideology is the concept of "rationality", introduced by the Dutch sociologist Mathias Matthijssen in his book

\footnotetext{
${ }^{21}$ Richard Batley, Oswald O’Brien \& Henry Parris, Going Comprehensive. Educational PolicyMaking in two County Boroughs (London, 1970), viii.

${ }^{22}$ Caroline Benn \& Clyde Chitty, Thirty Years on: Is Comprehensive Education Alive and Well, or Struggling to Survive? (London, 1996), p. 11.

${ }^{23}$ Paul Bellaby, The Sociology of Comprehensive Schooling (London, 1977).

${ }^{24}$ Willy Wielemans, "De evolutie van het secundair onderwijs in Europees perstpectief", in Willy Wielemans (Ed.), Vernieuwingen in het secundair onderwijs: een Europese situering. De actuele evolutie in de Duitse Bondsrepubliek - Engeland - Frankrijk - Nederland - Zweden: analyse en synthese (Leuven, 1986), pp. 93-136.
} 
De elite en de mythe [Elite and Myth], to describe the policy-making process. ${ }^{25}$ Rationality, after all, derives from cognitive and normative interpretation schemes that each person uses to interpret reality. Analogue to Habermas, Matthijssen describes cognitive schemes that we use to categorize events as true or untrue; the normative interpretation schemes require that conduct and events be categorized as good or bad. These schemes are applied as long as they prove successful in satisfying daily needs. However, if the user of such a scheme notices, on the basis of his/her experience, that these rules are inadequate, he/she will adjust his/her interpretation. When a cognitive interpretation scheme is elevated to a normative, the result according to Matthijssen is "rationality". In society, multiple rationalities operate side by side. The rationality that succeeds in solving the most crucial needs and problems in a society, and thereby is the most successful in everyday reality, becomes the dominant rationality. Provided that the ruling rationality succeeds in fulfilling the most vital needs in society, its dominance is preserved. But when a majority of the population no longer believes in its value it becomes unstable. Its dominance will be contested by alternative rationalities. Conflicts between opposing rationalities can lead to a new rationality taking dominance. But this does not mean that the slate is wiped clean; the old rationality continues to influence the new for quite some time, so that any transition to a new rationality is always gradual. In addition, a former dominant rationality would not just vanish but would remain in the collective conscience of the people. Furthermore, a dominant rationality is institutionalized in different subsystems of society. This influence does not disappear easily. Subsequently, these subsystems - for instance education - are perceived as maladjusted to the new rationality, resulting in a desire for educational reform.

Matthijssen speaks of a "technical rationality" becoming dominant in the first half of the nineteenth century as it replaced the older religious-literary rationality. Technical rationality is based on a strong belief in scientific progress and economic liberalism, and is typified by a bureaucratic organizational method. In his doctoral thesis, Roger Standaert demonstrated that the construction of secondary education policy in England and Wales, Germany and, to a lesser extent, France, is characterized by such technical rationality. ${ }^{26}$ In the second half of the twentieth century a new rationality emerged, described by Matthijssen as a "social rationality". The reform towards comprehensive education is interpreted by Matthijssen as part of a struggle of interests between technical and social rationalities. The prevailing technical rationality was still dominant at that time but was threatened by a new elite. The decline of comprehensive education in the 1980s-1990s could in this view be understood as the re-emergence of a technical rationality.

The main shortcoming of the concept of "rationality" is its limitation to the abstracted - global lines of action, and the fact that the prevalence of technical

\footnotetext{
${ }^{25}$ Mathias A.J.M. Matthijssen, De elite en de mythe: een sociologische analyse van strijd om onderwijsverandering (Deventer, 1982).

${ }^{26}$ Roger Standaert, De vlag in de top: over de rationaliteit van het secundair onderwijs-beleid: Frankrijk, Engeland en Wales, Duitse Bondsrepubliek (Leuven, 1990); the main conclusions of this research have been published in Roger Standaert, "Technical Rationality in Education Management: a Survey Covering England, France, and Germany", European Journal of Education, XXVIII (1993), pp. 159-175.
} 
rationality in the twentieth century insufficiently elucidates the changes in educational policy. The concept of "referential" fits better to explain policy shifts under a single dominant (technical) rationality. The "referential" is a concept from political science that tries to interpret the social vision of the political actors. To interpret the motives behind policy, the French political scientist Bruno Jobert makes use of that concept, pointing to "a group of beliefs, values and techniques that structure the scene of public politics" but at the same time "a group of tried and tested recipes that is believed to provide a response to those problems which have not yet been resolved". ${ }^{27}$ This concept, very similar to Kuhn's definition of a paradigm, ${ }^{28}$ can thus make reference to both the theoretical level (the values) and the practical level (the experience). The influence of a referential will be bigger if it is compatible - in this particular case - with the representations proper to the domain of educational policy, if it can be understood as conciliation between contradictory imperatives, if it is flexible enough to be interpreted by the main actors in their own terms.

In this respect, we could define the referential of education policy in postwar Western Europe as meritocratic. In meritocracy, fitting perfectly in the aforementioned technical rationality, personal merits became the foundations of social order, thus contrasting with the old aristocratic ideology in which descent and status prevailed. Applied to education, it was assumed that in offering equal starting positions, all pupils would have equal chances to success. In Belgium, these thoughts were reflected by the foundation of a National Study Fund (1954), which awarded grants for secondary and higher education to gifted children of limited means. But in the second half of the twentieth century, the dominant meritocratic view on education came under pressure. Sociological research had proved that democratizing the "input" factors, such as school fees, study grants and child support, did not reflect thoroughly the outcome of education. Psychological research showed that an objective criterion for judging talents at the age of twelve was an illusion. It was believed that, in order to achieve equal opportunities in school careers, one had to intervene in the structure of education, in teaching methods, assessment and coaching. This experience supported a social-progressive vision on the organization of education, described by some authors as a "new egalitarianism". ${ }^{29}$

The paradigm shift to a new prevailing referential was defined by post-materialist values. As Ronald Inglehart has shown in his book The Silent Revolution, the economic and technological development, the absence of "total war" during the past generation, the rising levels of education and the increase in geographic mobility, gave way to a post-materialist desire for social change in Western Europe and the USA in the $1960 \mathrm{~s} .{ }^{30}$ This would lead to the student revolts in the USA and

\footnotetext{
${ }^{27}$ Bruno Jobert, "Représentations sociales, controverses et débats dans la conduite des politiques publiques", Revue française de Science Politique, XLII (1992), p. 221 (my translation). See also Anne Van Haecht, "Les politiques éducatives, figure exemplaire des politiques publiques?”, Education et Sociétés, I (1998), pp. 21-46.

${ }^{28}$ See Thomas S. Kuhn, The Structure of Scientific Revolutions (Chicago, 1970).

${ }^{29}$ See C. Frankel, "The New Egalitarianism and the Old", Commentary, LVI (1973), pp. $54-66$.

${ }^{30}$ Ronald Inglehart, The Silent Revolution: Changing Values and Political Styles Among Western Publics (Princeton, 1977), p. 21.
} 
many European countries. Inglehart also refers to the introduction of such new political issues as women's emancipation, the quality of life, environmental issues etc. in the 1960s and 1970s. I would definitely also add the new ideas on the objectives of education as a part of this post-materialist "revolution". Contrary to Inglehart, however, I prefer to see this change as an evolution instead of a revolution. For these ideas were already (modestly) present in the educational policy of the 1950s and grew stronger throughout the years. The new views on education can be seen as the motor for some important reforms in Belgian secondary education, starting moderately with the harmonization of technical and grammar school education (1957), the creation of school files and class deliberation boards (1957) and of psycho-medico-social centres for pupil counselling (PMS, 1960). In 1963, a common Observation and Orientation Cycle was introduced in state secondary schools, though experiments go back to 1956. The democratization of university education was promoted by the Omnivalency Law (1964), which opened university entrance to pupils from several non-classical sections of secondary education, including the more academic technical sections provided they passed a "maturity" test.

Educational innovation was stimulated all over Europe in the 1960s. As early as 1964, the Council of Europe had taken a resolution in which the split between general and technical education was condemned because it perpetuated class discrimination. A few years later, in December 1968, the Council of Europe organized a colloquium in Düsseldorf, where important resolutions were taken that were later incorporated almost literally into the new education structure. In the Düsseldorfer Abkommen, the decision was taken to divide secondary education into three grades, starting with an observation grade, in which all pupils would get a largely common education and the final choice of study direction could be postponed, followed by an orientation grade, which focused more on the talents of the individual, in part by offering more choice of subjects, and finally a determination grade, where pupils could specialize as they chose. The preference was for a more "progressive" teaching method, with active, individualized education, making use of modern techniques, with the involvement of everyone. Learning to learn had to take priority over memorizing, and continuous assessment over separate examination. In terms of content, the choice was made for a crosssubject approach and for integration with current affairs, the social context and industry. The subjects would be divided into compulsory subjects, optional subjects and supplementary optional subjects. At an intergovernmental conference of Education Ministers of the European Economic Community at Versailles in May 1969, premature specialization was also condemned. The best chances for children from all social classes would only be guaranteed if determination were postponed until they were older. Pioneers in this context were Sweden (grundskola) and the UK (comprehensive school), but very similar reforms have been applied in the educational structures of Italy (scuola media), Germany (Gesamtschule), Ireland (comprehensive school), Belgium (reformed secondary education), France (collège unique), the Netherlands (middenschool), Denmark (folkeskole) and Norway (grunnskole).

The reason why comprehensive education came under pressure in these countries in the 1980 s could be related to the re-emergence of a technical rationality, though we prefer to refer to a changed referential. Since the economic crisis of the late 1970 s, the social objectives of reformed education have become 
outmoded. Recession and unemployment led to less trust in the future. Physiological (materialist) needs gained the upper hand over post-materialist needs. Guided by the experience of social and economic recipes, economic growth regained its place as a more dominant objective than social equality; individualism replaced community spirit. This was reflected in the education policy of many European countries, displaying a diminished sensitivity to the equality of educational chances. The priorities and perspectives of secondary education shifted towards more competitive and meritocratic values. ${ }^{31}$ Parents began to pay more attention again to the academic quality of schools, the "market value" of diplomas and, subsequently, labour opportunities for their children. Moreover, the economic crisis demanded "rationalizations" in the very costly RSE in Belgium. For school governors, the financial attractiveness to adopt this structure disappeared, and hence the appeal of the structure itself was lost.

In the UK, the new referential was clearly present in the conservative education policy in the 1980s, characterized by "consumerism", with "parental choice" and "market" as central ideas, with the teachers as producers and the parents as consumers. Since New Labour came to power in the UK (1997), no attempts have been made to revive the "old" Labour ideal of a genuine comprehensive nonselective schooling for democracy. On the contrary, Labour embraces "variety" in education and focuses on "modernizing" comprehensive secondary education. ${ }^{32}$ This might be interpreted as proof that the influence of changed referentials exceeds the influence of political discrepancies. Labour has combined the centralizing of educational powers with a transfer of administrative and financial responsibility to educational institutions. With this responsibilization of schools, together with funding being closely tied to participation rates, Labour has brought British education policy closer to the Conservative ideal than the Conservatives themselves ever could. ${ }^{33}$

In the Catholic school network in Flanders, representing $75 \%$ of secondary school pupils, the growth of the number of schools that had adopted the comprehensive structure stopped at the beginning of the 1980s, resulting in harsh competition between comprehensive schools and traditional schools, marketing "academic excellence". In order to overcome the deadlock, the leadership of the Catholic school network worked out a reconciling structure in the mid-1980s, based on the structure of comprehensive education, with a common stem and four branches (general, artistic, technical and vocational). But it made important concessions to the traditional education system (e.g. in the limitation of common hours in the first grade and in the limitation of optional subjects in the second and third grades). In 1989, the Christian-Democratic Minister of Education, Daniël Coens, imposed the "unitary school structure", which was based on the Catholic

\footnotetext{
${ }^{31}$ See, e.g., Gerry Fowler, "The Changing Nature of Educational Politics in the 1970s", in Patricia Broadfoot, Colin Brock \& Witold Tulasiewicz (Eds), Politics and Educational Change: an International Survey (London, 1981), pp. 13-28.

${ }^{32}$ For instance, the 1997 Education White Paper of Labour Secretary of State David Blunkett displays an enthusiasm for "modernizing" comprehensive secondary education. As Edwards, Whitty \& Power ("Moving Back", p. 31) note: "The Old Labour view, that if selection is wrong then it is wrong everywhere, seems to have been quietly forgotten".

${ }^{33}$ Jack Demaine, "Education Policy and Contemporary Politics", in Demaine, Education Policy and Contemporary Politics, pp. 5-29.
} 
compromise, on all Flemish secondary schools, public as well as private. This unitary type was to conciliate the traditional and comprehensive school structures. By 1991, a majority was found in the Flemish parliament to confirm this structure as the only legal school type for all of the secondary schools in Flanders. ${ }^{34}$ At first sight, the move towards a unitary school structure seems to be in contrast with the international trends to replace common schooling with more pluralist approaches. ${ }^{35}$ However, the Belgian educational landscape has always known a diverse system of school provision, with a large state-subsidized private sector that had a high degree of autonomy. This pluralism in school organization continued to exist, for the Decree determined only the boundaries between which schools could operate, leaving enough space to be filled by local education authorities to warrant diversity and the possibility of true choice for parents.

\section{Pragmatism as an important additional factor}

In constructing the history of comprehensive education, concepts such as "ideology", "rationality" and "referential" can be useful to elucidate policy fluctuations and conflicts. However, one cannot explain in detail why the reform did not achieve the success the initiators thought it would, without paying attention to pragmatism and practical problems. There have been many problems hindering the realization of a true comprehensive education system in Belgium. Sociologist Jef Verhoeven pointed to the lack of the expected and necessary in-service training of teachers, the frequent changes in the curriculum, the teacher transfers to other establishments, and the top-down imposition of innovation in state public schools, causing resistance to the reform among teachers. ${ }^{36}$ Contrary to state schools, free schools have never been forced to adopt the comprehensive model. The management of the Catholic school network supported the reform but did not have the power - some critics said, the courage - to apply it to all Catholic schools. To some extent, this worked favourably on the motivation of teachers and parents in the schools that wished to "go comprehensive". Certainly, in the early (experimental) years of the reform, the Catholic authorities admitted schools to the innovation experiment only if all the teachers and the local parents' association had agreed with it, and not just the board of management. But it also slowed the momentum of the innovation. On the other hand, since the adoption of the reform was left to the autonomy of the local Catholic school boards, a lot of practical and pragmatic reasons accompanied their choice. The motives for opting for comprehensive education in their schools were often rather "down to earth". It was frequently the more favourable subsidy conditions for comprehensive schools that convinced local school boards to make the transition. More interesting timetables,

\footnotetext{
${ }^{34}$ Decree on education II of 31 July 1990. In the French-speaking part of Belgium, the two old structures continued to run side by side. But I must comment that the "traditional" structures survived only in a few schools in the state-subsidized network and that the "comprehensive" structures in all the other educational institutions were restructured and modernized in the 1990s, thus resulting de facto also in a unitary type, more moderate and more pragmatic than the original RSE structures of 1969.

${ }^{35}$ See Edwards, Whitty \& Power, "Moving Back", p. 31.

${ }^{36}$ Jef Verhoeven, De leerkrachten uitgedaagd: een onderzoek over leerkrachten en onderwijsvernieuwing (Leuven, 1982). See also Willy Wielemans, "Comprehensive Education".
} 
with supplementary periods for coaching, made it possible for headmasters in comprehensive schools to keep young teachers at work, whereas their colleagues in traditional schools often had to make sacrifices.

The pragmatic reasons for choosing the comprehensive structure, the lack of good guidance and the (relative) autonomy of school boards in the Catholic network led to big differences in implementation of the teaching conditions of comprehensive education. Hence, comprehensive education in schools in the public education network differed widely from that in some Catholic institutions that only adopted the formal structure but changed nothing else. Those schools maintained the streaming of classes into strong and weak groups, as well as the old traditional teaching methods. Teachers continued to focus on the middle band of the class, devoting insufficient attention to individual coaching. Beverly Shaw, reporting the same findings for England and Wales, concluded that the acceptance of a comprehensive structure did not necessary imply the attainment of the goals of the innovation. ${ }^{37}$

With the necessary "rationalizations" around 1980, most of the practical advantages of the comprehensive structure disappeared. Together with a changed referential, this was one of the reasons for the breakdown in the growth of the comprehensive education sector. Another cause for the breakdown was the fact that in the Catholic sector of technical and vocational schools - mainly for organizational reasons - the curricula of traditional and comprehensive schools were tuned to one another. Thus the gap between the two school structures was narrowed. Technical and vocational schools introduced new curricula and teaching methods without having to adopt the comprehensive structure.

The motives for adopting the comprehensive structure, or maintaining the traditional form, were often linked to competition between schools. Comprehensive schools advertised in the early years the benefits of the reform, such as better pupil guidance, improved teaching and testing methods etc., in order to gain pupils from traditional schools. Following the adage "if you can't beat them, join them", in the regions where the school reform started, most of the schools changed over to the comprehensive structure. On the other hand, in the 1980s, when the appeal for comprehensive education was decreasing, the remaining traditional schools - in the network of Catholic schools, where the adoption of the comprehensive structure was left to choice - were competing with both state and Catholic comprehensive schools. This small minority of traditional schools started marketing "excellence" and "tradition" to cream off the brighter children and those of higher social class, thus hindering the comprehensive schools in realizing their objectivities.

The same evolution was apparent in the UK, where, according to Edwards, Whitty and Power, secondary education has become a "quasi market". Traditional academic values were being put forward to recruit middle-class children, and "the private sector continues to benefit hugely from marketing 'excellence' in that form, as do the surviving grammar schools and those comprehensives which try to resemble them". ${ }^{38}$ Since the introduction of league tables, constructing a local

\footnotetext{
${ }^{37}$ B. Shaw, Comprehensive Schooling: the Impossible Dream? (Oxford, 1983).

${ }^{38}$ Edwards, Whitty \& Power, "Moving Back", p. 34. See also Tony Edwards \& Geoff Whitty, "Marketing Quality: Traditional and Modern Versions of Educational Excellence", in Ron Glatter, P. Woods \& C. Bagley (Eds), Choice and Diversity in Schooling: Perspectives and Prospects (London, 1997).
} 
hierarchy of secondary schools, competition among schools has grown dramatically. At the same tempo that schools took on the comprehensive structure in the 1970 s, "in order to keep up", schools now felt obliged to follow the competition, and have decided to strengthen the conditions of admission, or to offer more academically focused branches.

We have also noted that certain Belgian politicians, although they did support social progressive ideology, kept defending traditional education because the traditional schools enjoyed great popularity in their constituencies. These remaining traditional schools resisted strongly the imposition of a unitary structure in 1989, taking the matter to court because of its supposed conflict with the constitutional freedom of education. However, the ruling of the Arbitration Court on 2 April 1992 dismissed the complaint. Again, ideological reasons have probably been less decisive in the action of these schools than the fact that their pupil population (and the related grants) had been rising in the preceding years, thanks to their competitive position. And indeed, as one could expect, these schools lost their surplus after the introduction of the unitary structure. As a matter of fact, one of the decisive reasons for the Belgian state public school network to accept and support the unitary structure, based on the compromise between Catholic schools, was the desire to gain back the pupils they had lost to (traditional) Catholic schools.

All these practical and pragmatic reasons implied that a genuine comprehensive school system could never be applied fully. Terry Haydn quotes a head teacher who remarked that, in England and Wales, too, "comprehensive schools ... have never been really tried. The presence of just one selective school - or a 15 per cent section within a school - to say nothing of independent schools, prevents the establishment of a truly comprehensive system." 39 As a result, one could argue that the objectives of comprehensive education could never been reached and, thus, all the comparisons between the outcome of comprehensive and traditional education are faulty. The same thing goes for current policy projects for educational innovation. The fact that Belgian state public schools cannot refuse pupils on ethnic or social grounds is an important step towards multicultural schooling. But as long as the Catholic schools preserve the right to refuse children, even if those refusals must be motivated by the fact that these children do not fit in their "confessional concept", state schools are bound to become "concentration schools", while Catholic schools can promote, once again, their "high quality" - not to say "elitist" or "white" characteristic. The inclusion of disabled children in "normal schools" - another important experiment in Belgian education over the next few years - is in this regard possibly doomed to fail as long as there are schools that can choose to opt out.

\footnotetext{
${ }^{39}$ Quoted in Terry Haydn, "The Strange Death of the Comprehensive School in England and Wales, 1965-2002". Paper presented at the XXIVth International Standing Conference for the History of Education (Paris, 2002), p. 8.
} 